\title{
Bioremediation of lead polluted soil from Obio/ Akpor local Government Area, rivers state using African Catfish and tilapia fish bones
}

\begin{abstract}
A study was undertaken to compare the bones of two fin fish-African Catfish (Clarias gariepinus) and Tilapia (Oreochromis niloticus), in the bioremediation of lead polluted soils. Six soil samples containing different sources of lead were collected from Obio-Akpor LGA, Rivers State. African catfish and Tilapia fishes were sourced from the market; the bones were extracted and dried (using a hot oven). The bones were then crushed with a blender, and weighed using analytical measuring scale. The crushed bones were mixed with lead polluted soil samples and left in the laboratory, in cool transparent plates for 3 weeks and 3 days for group one samples, while group two samples were left in the laboratory for 1 week and 3 days. The results revealed that for group one samples; Acid battery soil mixed with Catfish bones reduced the lead concentration from $3122.30 \mathrm{mg} / \mathrm{kg}$ to $2574.50 \mathrm{mg} / \mathrm{kg}$. Lead battery soil mixed with Tilapia bones reduced the lead concentration from $6718.15 \mathrm{mg} / \mathrm{kg}$ to $1184.15 \mathrm{mg} / \mathrm{kg}$, while Lead metal soil mixed with both Catfish+Tilapia bones increased the lead concentration from $8807.65 \mathrm{mg} / \mathrm{kg}$ to $11874.50 \mathrm{mg} / \mathrm{kg}$. For group two samples; Acid battery soil mixed with both Catfish+Tilapia bones reduced the lead concentration from $3706.75 \mathrm{mg} / \mathrm{kg}$ to $3144.45 \mathrm{mg} / \mathrm{kg}$. Lead metal soil mixed with Catfish bone reduced the lead concentration from $15940.50 \mathrm{mg} / \mathrm{kg}$ to $3903.90 \mathrm{mg} / \mathrm{kg}$, while Lead battery soil mixed with Tilapia bones increased the lead concentration from $6439.20 \mathrm{mg} / \mathrm{kg}$ to $11671.50 \mathrm{mg} / \mathrm{kg}$. The study revealed that Catfish bones, at different weights can be used in the bioremediation of lead polluted soils and the reduction was higher, than using Tilapia or the combination of the fish bones.
\end{abstract}

Keywords: catfish, tilapia, bones, lead, bioremediation, concentration
Volume 4 Issue 5 - 2019

Daniel UI, Nwanya A

Department of Animal and Environmental Biology, University of Port Harcourt, Nigeria

Correspondence: Daniel UI, Department of Animal and Environmental Biology, University of Port Harcourt, Nigeria, Email utibe.daniel@uniport.edu.ng

Received: August 19, 2019 | Published: September 26, 2019
Abbreviations: LBS, lead battery soil; LMS, lead metal soil; ABS, acid battery soil

\section{Introduction}

Lead exposure is a global issue since lead mining and smelting, and battery manufacturing, disposal and recycling are common in many countries. ${ }^{1}$ Lead enters the body through inhalation, ingestion or skin absorption. ${ }^{2}$ Almost all inhaled lead is absorbed into the body. For ingestion, the rate is $20-70 \%$ with children absorbing a higher percentage than adults. For ingestion poisoning typically results from ingestion of food or water contaminated with lead or less commonly after accidental ingestion of contaminated soil, dust or lead based paint. Sea water product can contain lead if affected by nearby industrial waters. Fruits and vegetable can be contaminated by high level of lead in the soils they are grown. ${ }^{3}$

Lead can accumulate in the soil, especially those with a high organic content, where it remains for hundreds to thousands of years. ${ }^{4}$ Environmental lead can compete with other metals found in and on plant surfaces potentially inhibiting photosynthesis and at high enough concentration negatively affecting plant growth and survival. Contamination of soils and plant can allow lead to ascend the food chain affecting micro-organism, animals and humans. ${ }^{5}$ Much of the lead dispersed by man is eventually washed into natural waters and is presumably precipitated into the sediments. The methylation of mercury and arsenic by microorganisms in the environment has been documented and well summarized. Nothing, however, has been known about the existence of organic forms of lead in the environment as a result of biotransformation. ${ }^{6}$

Fish bones are largely known to be made of calcium and phosphate mineral apatite, which helps to immobilize other potentially toxic metals such as copper, zinc, and lead. The phosphate contained in the bones of fishes does not run off the soil, thereby making it possible for the phosphate to readily combine with these heavy metals. When combined, it forms a Pyromorphite; a stable crystalline mineral which is not toxic. The chemical composition of most fish bones varies significantly. Due to this mineral content, it has been cited that fish bones are well suitable as a natural calcium source. More importantly, it is the grinding up of fish bones and mixing them into the soil but it is not so much the bones themselves that make the difference as the calcium phosphate that they contain. The study therefore is aimed to exploit crushed fish bone in the extraction/bioremediation of lead polluted soil.

\section{Materials and methods}

\section{Sample collection/experimental design}

Six different samples were collected from a mechanic workshop in Obio/Akpor LGA, Rivers State. The first set of the soil samples were collected from a mechanic workshop located at A.P filling station Abuja park main gate, along the East West road, University of Port Harcourt in Obio/Akpor LGA ( $4^{\circ} 53^{1} 40,9^{\prime}$ N, $6^{\circ} 54^{1} 48.2$ ” E). 
The second set of the soil samples were collected at another mechanic workshop located at first mechanic Alakahia, along the East West Road in Obio/Akpor LGA(4 $4^{\circ} 53^{1} 20.2^{\prime \prime} \mathrm{N}, 6^{\circ} 55^{1} 18.5^{\prime}$ E). The soil samples were collected using a black polythene bag and were later transferred into transparent plastic plates with covers. The samples were grouped into two. Group one includes the first set samples that were collected, which were divided in to three plastic plates. Plate 1(lead battery soil), Plate 2(lead metal soil) and Plate 3 (acid battery soil) all weighed $0.41 \mathrm{~kg}$. Group two includes the second set of samples that were collected, which were also divided in to three plates, making a total of six (6) plastic plates with 6 soil samples.Plate 1 (lead battery soil) weighed $0.15 \mathrm{~kg}$, Plate 2 (lead metal soil) weighed $0.34 \mathrm{~kg}$ and Plate 3 (acid battery soil) weighed $0.35 \mathrm{~kg}$. The fishes (Tilapia and Catfish) were bought from slaughter market located at Rumuomasi, Port Harcourt, Rivers State. For group one fish bones, Catfish bones weighed 100g, Tilapia bones weighed 100g and Catfish+Tilapia bones also weighed $100 \mathrm{~g}$. For group two fish bones, Catfish bones weighed 719.20g; Tilapia bones weighed $310.20 \mathrm{~g}$ while Catfish+Tilapia bones weighed $617.30 \mathrm{~g}$. Using the randomized block design, a comparative analysis was carried out in the bioremediation of lead polluted soil samples.

\section{Physiochemical parameters of the soil}

Soil sample sizes: The first set of the soil Sample was divided into 3 plates. Plate 1 contained soil sample from the mechanic workshop where lead battery were worked on. This plate is also known as Lead Battery Soil (LBS). This was weighed with a weighing balance.

Plate 2 from the first set, contained soil sample which was mixed with lead metal. This plate is also known as (LMS). Plate 3 contained soil sample that was mixed with acidic water from lead. This plate is also known as (ABS) or Acid Battery Soil.

The second set of the sample were divided into 3 new plates. Plate 1 also contained lead battery from where lead battery where worked on, and analytical scale was used. Plate 2 which is known as the LMS (Lead Metal Soil) was weighed giving a scale of $335.03 \mathrm{~g}$. Plate 3 (ABS) was weighed giving a scale of $345.46 \mathrm{~g}$

\section{Heavy metal content}

The first set of soil samples were tested in the laboratory for Lead ion using the following procedure:

The sample was washed in a muffle furnace at a temperature of $630^{\circ} \mathrm{C}$ for 3 hours. The ash sample was dissolved in $10 \mathrm{ml}$ concentrated Hydrochloric Acid and was heated on an electro-thermal heater hot plate. The solution of the ash was diluted to $50 \mathrm{ml}$ with distilled water. The solution was analyzed for metal ion by Atomic Absorption Spectrophotometer.

Lead ion was analyzed by an Atomic Absorption Spectrophotometer at $283.3 \mathrm{~mm}$ wave length. The wavelength was selected with a narrow slit with arc and acetylene gas flow was adjusted. Other setting as recommended for the instrument employed was attended to and regulated hallow cathode amp was given adequate time to stabilize before aspirating standards for equipment calibration. After calibrating the equipment with standards lead concentration, the aspiration tubing and system were flushed with distilled water severally before aspirating the test sample solution on the sample experimental condition used for the standard. The concentration of the lead ion in the sample was extrapolated from the standard. Graph of lead ion plotted in the concentration was expressed in ppm from the equipment and corrections were made necessary in unit of choice.
Fish bone utilization/preparation: Fresh Catfish and Tilapia fishes were bought from the market. The bones of these fishes were extracted and put in an oven, drying at more than $60^{\circ} \mathrm{C}$ for 30 mins. After the drying, the bones were crushed by grinding them in a blender. The crushed bones were later weighed and weights were recorded.

\section{Fish bone and soil amalgamate}

The crushed fish bones were mixed with their respective soil samples. The first set of soil sample and respective fish bone mixtures include:

A. GROUP 1:
i. Plate 1 (LBS) was mixed with Tilapia fish bone
ii. Plate 2 (LMS) was mixed with Catfish and Tilapia bone
iii. Plate 3 (ABS) was mixed with Catfish bone.

B. GROUP 2:
i. Plate 1 (LBS) was mixed with Tilapia fish bone
ii. Plate 2 (LMS) was mixed with cat fish bone
iii. Plate 3 (ABS) was mixed with Catfish and Tilapia bone.

\section{Time Duration}

a. The first group of fish bone and lead soil were amalgamated and were left in a cool dry place away from sunlight.

b. The time duration given for the process of amalgamation was 3 weeks and 3 days ( 24 days).

c. The second group of fish bone and lead soil were also amalgamated and kept in a cool dry place away from sunlight.

d. The time duration given for the process was 1 week and 3 days (10 days). Although the second set of sample were prepared with lead and were left 2 weeks longer before they were amalgamated with the fish bones.

\section{Fish bone weights}

Both groups one and group two fish bones were extracted and steamed in an oven. After steaming, the fish bones were grinded using an electric grinder. the fish were grinded with a blender and weighed in the laboratory.

\section{Results}

\section{Soil sample sizes}

The soil sample sizes were weighed using different scale measurements. The weight of the different soil sample for the different groups as shown in Table 1 indicates the sample sizes of the lead polluted soils in group 1 . The lead battery soil weighed $0.41 \mathrm{~kg}$ upon measurement. The lead metal soil weighed $0.41 \mathrm{~kg}$ upon measurement and the acid battery soil also weighed $0.41 \mathrm{~kg}$ upon measurement.

Table I Sample sizes of the lead polluted soils in Group I

\begin{tabular}{lll}
\hline S/N & Soil type & Weight of soil (kg) \\
\hline I & Plate I (Lead Battery Soil) & $0.4 \mathrm{I} \mathrm{kgw}$ \\
2 & Plate 2 (Lead Metal Soil) & $0.4 \mathrm{I} \mathrm{kg}$ \\
3 & Plate 3 (Acid Battery Soil) & $0.4 \mathrm{l} \mathrm{kg}$ \\
\hline
\end{tabular}


Table 2 indicates the sample size of the lead polluted soils collected for group 2 . The lead battery soil weighed $0.15 \mathrm{~kg}$; the lead metal soil weighed $0.34 \mathrm{~kg}$ while the acid battery soil weighed $0.35 \mathrm{~kg}$.

Table 2 Sample size of the lead polluted soils collected for Group 2

\begin{tabular}{lll} 
S/N & Soil type & Weight of soil (kg) \\
\hline I & Plate I (Lead Battery Soil) & $0.15 \mathrm{~kg}$ \\
2 & Plate 2 (Lead Metal Soil) & $0.34 \mathrm{~kg}$ \\
3 & Plate 3 (Acid Battery Soil) & $0.35 \mathrm{~kg}$ \\
\hline
\end{tabular}

\section{Heavy metal content analysis}

Before bone mixture, group one and group two soil samples contained different quantity of lead upon analysis.

The Table 3 shows the concentration of lead in the soil samples for group 1 before bioremediation. Acid battery soil weighed $3122.30 \mathrm{mg} /$ $\mathrm{kg}$, lead battery soil weighed $6718.15 \mathrm{mg} / \mathrm{kg}$, while lead metal soil weigh $8807.65 \mathrm{mg} / \mathrm{kg}$

Table 3 Lead $(\mathrm{Pb})$ concentration in Group I

\begin{tabular}{lll}
\hline $\mathbf{S} / \mathbf{N}$ & Sample identity & $\mathbf{P b}(\mathbf{m g} / \mathbf{k g})$ \\
\hline I & Acid Battery soil & $3 \mid 22.3$ \\
2 & Lead Battery soil & $67 \mid 8.15$ \\
3 & Lead Metal soil & 8807.65
\end{tabular}

The result on Table 4 shows the concentration of lead in the soil samples for group 2 before bioremediation with fish bone. Acid battery soil weighed $3706.75 \mathrm{mg} / \mathrm{kg}$, Lead battery soil weighed $6439.20 \mathrm{mg} / \mathrm{kg}$ while Lead metal soil weighed $15940.50 \mathrm{mg} / \mathrm{kg}$.

Table 4 Lead $(\mathrm{Pb})$ concentration in Group 2

\begin{tabular}{lll}
\hline S/N & Sample identity & $\mathbf{P b}(\mathbf{m g} / \mathbf{k g})$ \\
\hline I & Acid Battery soil & 3706.75 \\
2 & Lead Battery soil & 6439.2 \\
3 & Lead Metal soil & 15940.5
\end{tabular}

\section{Fish bone weights}

The result on Table 5 shows the weight of fish bones used in group 1. Catfish bones weighed $100 \mathrm{~g}$, tilapia bones weighed $100 \mathrm{~g}$, while the combination of both catfish + tilapia bones weighed $100 \mathrm{~g}$.

Table 5 Weight of fish bones for Group I

\begin{tabular}{lll}
\hline $\mathbf{S} / \mathbf{N}$ & Type of fish & Weight of fish bone \\
\hline 1 & Catfish & 100g \\
2 & Tilapia & $100 \mathrm{~g}$ \\
3 & Catfish + Tilapia & $100 \mathrm{~g}$
\end{tabular}

Table 6 shows the weight of fish bones used in group 2. Catfish bones weighed $719.20 \mathrm{~g}$, tilapia weighed $310.20 \mathrm{~g}$, while the combination of both catfish + tilapia bones weighed $617.30 \mathrm{~g}$.
Table 6 Weight of fish bone for group two

\begin{tabular}{lll}
\hline S/N & Type of fish & Weight of fish bone \\
\hline 1 & Catfish & $719.20 \mathrm{~g}$ \\
2 & Tilapia & $310.20 \mathrm{~g}$ \\
3 & Catfish + Tilapia & $617.30 \mathrm{~g}$ \\
\hline
\end{tabular}

\section{Physical parameters of the soil}

The amalgamate of fish bone and soil samples, having been left for some weeks developed some changes which as discussed below:

Dryness: there was an ashen dryness to the soil. This was observed a few weeks after the crushed fish bones were left with the lead soil samples. The Acid Battery soil plates were particularly dry and it was observed that the mixture that was seen due to the mixture of acidic water with the soil was no longer seen.

Growth of Mold: This growth was seen in some of the fish bone residues that did not amalgamate properly with the soil.

Table 7 shows the concentration of lead in the soil samples for group 1 after bioremediation. Lead metal soil weighed $1187.50 \mathrm{mg} /$ $\mathrm{kg}$, Lead battery soil weighed $1184.15 \mathrm{mg} / \mathrm{kg}$ and Acid battery soil weighed $2574.50 \mathrm{mg} / \mathrm{kg}$.

Table 7 Heavy metal concentration after bone mixture for Group I

\begin{tabular}{lll}
\hline $\mathbf{S} / \mathbf{N}$ & Sample identity & $\mathbf{P b}(\mathbf{m g} / \mathbf{k g})$ \\
\hline $\mathbf{I}$ & Lead Metal soil & $\mathrm{I} / 87.5$ \\
2 & Lead Battery soil & $1 / 84.15$ \\
3 & Acid Battery soil & 2574.5 \\
\hline
\end{tabular}

Table 8 shows the concentration of lead in the soil sample for group 1 after bioremediation. Lead metal soil weighed $3903.90 \mathrm{mg} /$ $\mathrm{kg}$, Lead battery soil weighed $11671.50 \mathrm{mg} / \mathrm{kg}$ and Acid battery soil weighed $3144.45 \mathrm{mg} / \mathrm{kg}$.

Table 8 Heavy metal concentration after bone mixture for Group 2

\begin{tabular}{lll}
\hline $\mathbf{S} / \mathbf{N}$ & Sample identity & $\mathbf{P b}(\mathbf{m g} / \mathbf{k g})$ \\
\hline $\mathrm{I}$ & Lead Metal soil & 3903.9 \\
2 & Lead Battery soil & 11671.5 \\
3 & Acid Battery soil & 3144.45
\end{tabular}

Table 9 shows the concentration of lead in soil sample before and after the bioremediation with fish boxes. Acid battery soil with catfish bone reduced in lead concentration from $3122.30 \mathrm{mg} / \mathrm{kg}$ to $2574.50 \mathrm{mg} / \mathrm{kg}$, Lead battery soil with tilapia bone reduced the lead concentration from $6718.15 \mathrm{mg} / \mathrm{kg}$ to $1184.15 \mathrm{mg} / \mathrm{kg}$ and Lead metal soil with catfish + tilapia bone increased the lead concentration from 8807.6 to $11874.50 \mathrm{mg} / \mathrm{kg}$

Table 9 shows the concentration of lead in soil sample before and after the bioremediation with fish boxes. Acid battery soil with Catfish+Tilapia bones reduced in lead bio-concentration from $3706.75 \mathrm{mg} / \mathrm{kg}$ to $3144.45 \mathrm{mg} / \mathrm{kg}$, Lead battery soil with tilapia bone increased the lead concentration from $6439.20 \mathrm{mg} / \mathrm{kg}$ to $11671.50 \mathrm{mg} /$ $\mathrm{kg}$ and Lead metal soil with catfish bone reduced the lead concentration from 15940.50 to $3903.90 \mathrm{mg} / \mathrm{kg}$.

From Group 1 samples; Tilapia bone was able to bioremediate lead battery from $6718.15 \mathrm{mg} / \mathrm{kg}$ to $1184.15 \mathrm{mg} / \mathrm{kg}$ in 3 weeks. Catfish 
bone was able to bioremediate acid battery soil from $3122.30 \mathrm{mg} / \mathrm{kg}$ to $2574.50 \mathrm{mg} / \mathrm{kg}$ in 3 weeks. Tilapia and catfish bone increased the concentration of lead metal soil from $8807.65 \mathrm{mg} / \mathrm{kg}$ to $11874.50 \mathrm{mg} /$ $\mathrm{kg}$ in 3 weeks. From Table 9, only lead metal sample increased in lead concentration. The two other plates (lead battery and acid battery) decreased in lead concentration from previous chapters, it can be seen that the Acid battery sample was bioremediated with catfish bone. Lead battery sample was mixed with Tilapia fish bone while lead metal sample was mixed with both catfish and Tilapia bone.
From Group 2 samples; Tilapia fish bone increased the concentration of lead battery soil from $6439.20 \mathrm{mg} / \mathrm{kg}$ to $11671.50 \mathrm{mg} /$ $\mathrm{kg}$ in 1 week. Catfish bone was able to bioremediate lead metal soil from $15940.50 \mathrm{mg} / \mathrm{kg}$ to $3903.90 \mathrm{mg} / \mathrm{kg}$ under 1 week. Tilapia and Catfish bone was able to bioremediate Acid battery soil from $3706.75 \mathrm{mg} / \mathrm{kg}$ to $3114.45 \mathrm{mg} / \mathrm{kg}$ in 1 week. From Table 10, acid battery sample which was mixed with both catfish and Tilapia fish bone reduced in lead concentration. Lead battery which was mixed with Tilapia bone increased in concentration of lead metal which was mixed with only Catfish bone reduced in lead concentration.

Table 9 Heavy metal concentration before and after bone mixture for Group I

\begin{tabular}{cllll}
\hline S/N & Sample identity & Bone & $\begin{array}{l}\text { Lead concentration before } \\
\text { bioremediation }\end{array}$ & $\begin{array}{l}\text { Lead concentration after } \\
\text { bioremediation }\end{array}$ \\
\hline I & Acid Battery & Catfish & $3122.30 \mathrm{mg} / \mathrm{kg}$ & $2574.50 \mathrm{mg} / \mathrm{kg}$ \\
2 & Lead Battery & Tilapia & $6718.15 \mathrm{mg} / \mathrm{kg}$ & $1184.15 \mathrm{mg} / \mathrm{kg}$ \\
3 & Lead Metal & Catfish+Tilapia & $8807.65 \mathrm{mg} / \mathrm{kg}$ & $11874.50 \mathrm{mg} / \mathrm{kg}$ \\
\hline
\end{tabular}

Table 10 Heavy metal concentration before and after bone mixture for Group 2

\begin{tabular}{lllll}
\hline S/N & Sample identity & Bone & $\begin{array}{l}\text { Lead concentration before } \\
\text { bioremediation }\end{array}$ & $\begin{array}{l}\text { Lead concentration after } \\
\text { bioremediation }\end{array}$ \\
\hline I & Acid Battery & Catfish+Tilapia & $3706.75 \mathrm{mg} / \mathrm{kg}$ & $3144.45 \mathrm{mg} / \mathrm{kg}$ \\
2 & Lead Battery & Tilapia & $6439.20 \mathrm{mg} / \mathrm{kg}$ & $11671.50 \mathrm{mg} / \mathrm{kg}$ \\
3 & Lead Metal & Catfish & $15940.50 \mathrm{mg} / \mathrm{kg}$ & $3903.90 \mathrm{mg} / \mathrm{kg}$ \\
\hline
\end{tabular}

\section{Discussion}

Fish bones are made of the phosphate mineral apatite, which readily combines with lead to form pyromorphite, a stable crystalline mineral that can't be absorbed by the human digestive system ${ }^{7,8}$ Crushed fish bones are the surprising solution for lead contaminated soil. The importance of bone meal has been reported (The Columbia Encyclopaedia, Sixth Edition, 2001) as an organic fertilizer source due to its readily available phosphate and nitrogen (about 23-30\% available phosphate and $2-4 \%$ nitrogen) content. In addition, bone meal has been used as a feed supplement to farm animals to provide crucial mineral food constituents (i.e., calcium and phosphorus). According to a report by Suzanne, ${ }^{9}$ fish bones were used to get lead out of soil in West Oakland. Rows of bulging white one-ton sacks of ground fish bone from Alaska were lined up inside a shed in South Prescott neighbourhood. In the coming months, workers tilled the bones into lead-contaminated soil, where it binded with the toxic metal as it decayed creating a tiny, harmless crystal. In situ and laboratory tests have also shown that phosphates in fish bones can immobilize other potentially toxic metals. In one of these studies, lead concentrations in soil leachate treated with fish bones dropped from $0.28 \mathrm{mg} / \mathrm{L}$ to $0.00065 \mathrm{mg} / \mathrm{L}$ within weeks.

Valsami- Jones et al. ${ }^{10}$ noted similarities between some synthetic apatites and bone meal. They suggested that poorly crystalline apatites such as those found in crush bone (bone meal) could therefore provide a cost-effective, natural-phosphate source for remediation of soils contaminated with certain metals. In most of the experiments related to remediation of metal contaminated soils, application of bone meal was found to be a suitable source of phosphate for such remediation. ${ }^{11}$

From the result of this study, the fish bone and soil amalgamate gave different results either depending on the different lead sample, the type of fish bone, or the time duration each group was given to bioremediate.

\section{Conclusion}

The study has shown clearly, that catfish bones can be used to bioremediate lead polluted soils. This means that the lead percentage can be at any rates and the types of lead soil may vary, under different time duration, but the weight of the catfish bone either at $100 \mathrm{~g}$ or $300 \mathrm{~g}$ will be able to bioremediate the soil.

Therefore, the use of fish bone turning from waste to wealth or reducing health risk in our environment is hereby advocated.

\section{Acknowledgments}

I wish to acknowledge Prof. Mrs. A.I. Hart and Prof. F.D.Sikoki for their for their encouragement and support in my career pursuit. My wife Mrs. Unwana Daniel and my son Destiny Daniel for their prayers and moral support. Finally, wish to acknowledge my research assistant Mr. Maxwell for typesetting the article.

\section{Funding}

The research was self sponsored

\section{Conflicts of interest}

The authors declare that there is no competing of interest.

\section{References}

1. Lim ST, Murphy T, Wilson K, et al. Leaded paint in Cambodia-PilotScale Assessment. J Health Pollut. 2015;5(9):18-24.

2. Plumlee GS, Durant JT, Morman SA, et al. Linking geological and health sciences to assess childhood lead poisoning from artisanal gold mining in Nigeria. Environmental Health Perspectives. 2013;,121(6):744-750. 
3. Tong S, Vasmin EVS, Prapamontol T. Environmental lead exposure: a public health problem of global dimensions. Bull World Health Organ. 2000;78(9):1068-1077.

4. Oguzie FA. Heavy metals in fish, water and effluents of lower Ikpoba River, Benin City. Pakistan Journal of Science and Industrial Research. 2003;46(3):156-160.

5. Fytianos K, Katsianis G, Triantafyllou P, et al. Accumulation of heavy metals in vegetables grown in an industrial area in relation to soil. Bull Environ Contam Toxicol. 2001;67(3):0423-0430.

6. Beyer WN, Audet DJ, Heinz GH, et al. Relation of waterfowl poisoining to sediment lead concentrations in the Coeur d'Alene River Basin. Ecotoxicology. 2000;9(3):207-218.

7. Miretzky P, Fernandez-Cirelli A. Phosphates for $\mathrm{Pb}$ immobilization in soils: a review. Environ Chem Lett. 2008;6(3):121-133.
8. Wright J. PIMS using apatite II $^{\mathrm{TM}}$ : How it works to remediate soil and water. In: Hinchee RE, Alleman B, editors. Proceedings of the Conference on Sustainable Range Management, 5-8 Jan 2004. Sustainable Range Management-2004, Columbus, OH: Battelle Press; 2004.

9. Suzanne F. Factors controlling biological availability and toxic effects of lead in aquatic organisms. Sci Total Environ. 2011;79(2):157-169.

10. Valsami-Jones E, Ragnardottir KV, Mann T, et al. Dissolution of apatite ion the presence of metal cations in aqueous solution. Chem Geol. 1998;151(1-4):215-233.

11. Laperche $\mathrm{V}$, Traina SJ. Immobilization of $\mathrm{Pb}$ by Hydroxylapatite. In: Jenne EA, editor. Adsorption of metals by geomedia. New York: Academic Press; 1998:255-276. 